\title{
Tree Conservation Challenges among the Indigenous Pastoral Rendille Community in Marsabit, Kenya
}

\author{
Janet Ahatho Ekalo ${ }^{1 *}$, James Koske ${ }^{1}$, Cecilia Gichuki ${ }^{1}$ and Innocent Ngare ${ }^{1}$ \\ ${ }^{1}$ Department of Environmental Sciences and Education, School of Environmental Studies, \\ Kenyatta University. P.O.Box 43844 - 00100 GPO, Nairobi, Kenya. \\ Authors' contributions \\ This work was carried out in collaboration among all authors. Author JAE development of the \\ manuscript, Authors JK, CG Review of literature relevant materials, Author IN Compiling of the \\ manuscript, proofreading and formatting. All authors read and approved the final manuscript.
}

Article Information

DOI: $10.9734 / A J G R / 2021 / v 4 i 390$

Editor(s):

(1) Dr. Armando García Chiang, Universidad Autónoma Metropolitana-Iztapalapa, México.

Reviewers:

(1) Mohammed S. Eldaghmah, University for Security Sciences, Saudi Arabia

(2) Prantik Banerjee, Adamas University, India.

Complete Peer review History: https://www.sdiarticle4.com/review-history/70332

Original Research Article

Received 02 May 2021

Accepted 07 July 2021

Published 13 July 2021

\begin{abstract}
Every environment is surrounded by traditional people who have lived in the geographic location for a long time and use their particular knowledge to cohabit with the natural ecosystem. This study assessed challenges encountered towards tree conservation by the Rendille pastoral community in Kenya. Selected tree species; Olea europaea, Terminalia sp. and Hyphaene compressa, that are commonly used by the community were identified and the probable threats towards their conservation. Some of these tree conservation challenges by the indigenous Rendille were: charcoal burning and fuel wood consumption, demand of traditional tree medicinal value, climate variability extremes and demand for land for settlement by the community. The results indicate that, charcoal burning $(84.4 \%)$ and demand for traditional tree medicine $(77.3 \%)$ were leading causes frustrating tree conservation among the Rendille. To mitigate these challenges, the respondents indicated that, creation of awareness $(89.1 \%)$ and promotion of other sources of fuel $(78.9 \%)$ could be vital factors. The study recommends Integration of Indigenous Knowledge (IK) with formal education to enhance conservation of the mentioned tree species.
\end{abstract}


Keywords: Tree conservation; challenges; ecosystem; environment; olea europaea; terminalia sp.; hyphaene compressa.

\section{INTRODUCTION}

Rural communities have relied on local knowledge to maintain their habitats for millennia [1]. Rural people have established a body of knowledge on forest and wildlife protection by learning through experiences, imitating, and observing. In this sense, conservation refers to the procedures of preserving, safeguarding, and managing forest and wildlife resources. For the supply of ecosystem products and services, spiritual and cultural values, and nutrient cycles, forests are essential. Many of these commodities and services rely heavily on biodiversity. Forest and wildlife resources, on the other hand, are disappearing at an alarming rate around the world (Dudley et al., 2014). Between 1995 and 2015, the globe lost about 70 million hectares of primary forest. While enormous swaths of forest are being burned to support growing lumber companies, other woods face wildfire dangers. Forest degradation has steadily reduced biodiversity, scenic views of landscapes, and ecological functions such as the production of commodities and services for human needs. The loss of biodiversity has a negative impact on rural livelihoods and threatens the food, energy, and health security of local populations. Drivers of biodiversity loss may also increase land degradation, habitat loss for migratory species, soil fertility deterioration, and tourism potential [2]. Threatened ecosystems through human overexploitation, results to ecosystem degradation threshold. Therefore, the ecosystem fails to support it carrying capacity leading to extinction of animals and microorganism and habitat loss (Kimaro \& Muturi, 2013). These ecosystem stressors include; climate change, forest fires, invasive species, and eutrophication. Thus, these environmental problems need prudent ecosystem conservation measures. According to [3], ecosystem conservation is the wise or innovative use of natural resources for a sustainable society. These inventions can be either modern innovations or traditional inventions. It is difficult to exist without interacting with the environment. However, these interactions at some point neglected the bio capacity rate of nature as nations and individuals focus on the economic growth that degrade the physical environment. Most companies depend on nature for raw materials like timber, fiber and fruits [4] indigenous people depend on it for medicine and food through hunting and gathering.

The setbacks that result on unequivocal utilization of the natural environment include; massive soil erosion and landslides, loss of biological and key indicator species [5]. Ecosystem conservation can be through afforestation, reforestation, and agroforestry to enhance the microclimate, using of organic manure to enhance soil fertility and reduce eutrophication. Environmental education [6] is also a way of bringing communities together for awareness, skill development and participatory approaches in conservation activities to change values and attitudes towards sustainable environment and ecosystem restoration [7]. However, most of these ways are modern and require a lot of resources. Therefore, it is a noble idea to consider the indigenous knowledge systems in ecosystem conservation and restoration which is realistic and viable to implement. In addition, modern innovations can be integrated with the indigenous knowledge system for a collective participatory approach.

Every ecosystem is surrounded by specific traditional people that have lived in it for a long period of time and usetheir unique knowledge to coexist. Marsabit County is a green island in Chalbi desert in the Northen Kenya with a variety of mountains and Marsabit tropical rainforest with evergreen forest cover with species like Cassipourea malosana, Podocarus gracilior, Olea africana, Juniperus procera and, Croton megalocarpus [8]. This ecosystem is very fragile within the desert therefore requires maximum attention by the government and the communities such as the Gabbra, Samburu and the Rendille. The study assessed tree conservation challenges within the Rendille community in Kenya.

\section{METHODOLOGY}

The study used a descriptive research design to collect data among the Rendille pastoral community in Marsabit County, Kenya. To sample the respondents, systematic random sampling was employed at community household level to assess tree conservation challenges. A total of 128 respondents were sampled through probability sampling. A closed ended 

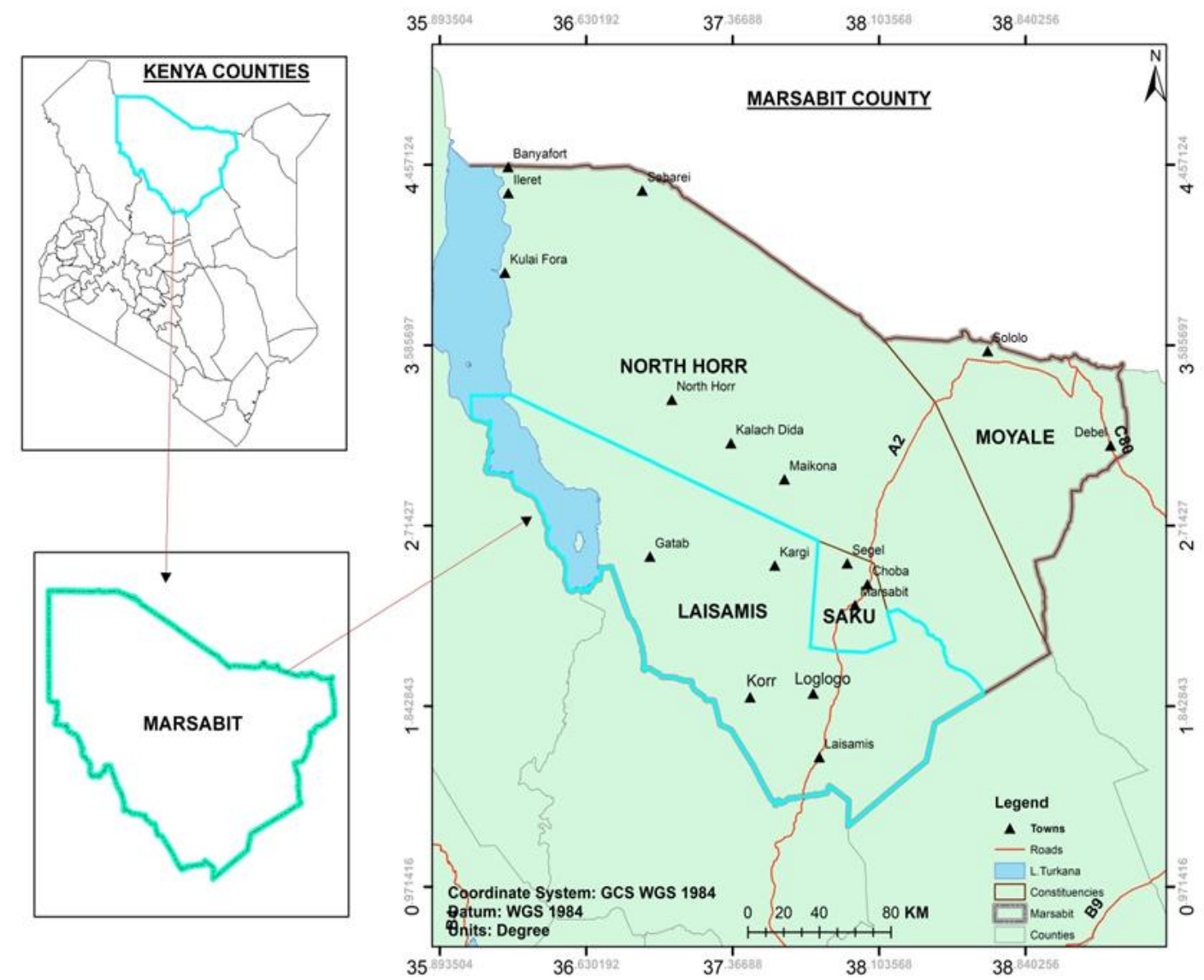

Fig. 1. Map of Marsabit County, Kenya

questionnaire was used as a primary data collection tool. Data analysis was through Statistical Package of Social Scientists.

\subsection{Study Area}

This is study was carried out in Marsabit county previously North Eastern province [9]. It is a dry land that falls in ASALs in Kenya. The county boarders Ethiopia to the North, to the west Turkana County, to the south Samburu and Isiolo County and to the East Wajir County (Muthini \& Munguti, 2013). Marsabit county lies within latitude $02^{\circ} 45^{\circ} \mathrm{N}$ and $04^{\circ} 27^{\circ} \mathrm{N}$ and longitude $37^{\circ} 57^{\circ} \mathrm{E}$ and $39^{\circ} 21^{\circ} \mathrm{E}$ [10]. The County is isolated in the extreme North of Kenya about $529.5 \mathrm{Km}$ from Nairobi Capital City. Marsabit county is the largest county in Kenya that covers a landmass area of $70,916.2 \mathrm{KM}^{2}$ with an estimated population of 459785 persons according to 2019 Kenya Population and Housing census [11].

\section{RESULTS AND DISCUSSION}

\subsection{Conservation Challenged on Selected tree Species among the Rendille Community}

Results on Table 1, indicate the challenges facing the conservation of $O$. europaea, $T$. nobilis, Terminalia spp. and $H$. compressa among the Rendille community were mainly; charcoal burning $(84.4 \%)$, traditional medicine $(77.3 \%)$, climate variability extremes like prolonged drought, high temperature, unpredictable rainfall pattern $(73.4 \%)$, timber trading $(47.7 \%)$ and demand for land at $(42.2 \%)$ especially for agricultural land and establishment of structures such as settlement schemes.

These conservation challenges were ranked in a scale of 1-5 where; 1 on scale represents the biggest challenge as 5 represents the least challenge on conservation of selected trees. 
From the results, charcoal burning and fuel consumption was ranked as leading major challenge $(n=108,84.4 \%)$ faced by the Rendille community on tree conservation. The second conservation challenge of concern was demand for traditional medicine $(n=99,77.3 \%)$ by the Rendille community. Other least viewed challenges by the respondents were timber trading at $47.7 \%$ and demand for land at $42.2 \%$. Climate variability extremes challenge towards conservation was viewed to be above average with a responded ranking index of $73.4 \%$ by the respondents. From the results, it can be noted that demand for forest resources is overburdened by increasing population in Marsabit by the Rendille community to sustain their socioeconomic livelihoods.

Globally, forests are critical in providing numerous services, both productive and ecological. Forests not only regulate the hydrological processes and pollution, but they are also essential in mitigating climate change [12]. Through habitat loss and demand of forest resources have proliferated decline of forests from 4,128 billion hectares in 1994 to 3,999 billion hectares in 2015 around the world [13]. The study indicates that, global south countries depend on forest resources for biomass energy and timber production. Indigenous communal forests are further threatened in Kenya with their unique hardwood trees that enhance their demand. However, the results (Table 1) find charcoal burning and demand for traditional medicine consequential to selected tree species among the Rendile community in Kenya.

\subsection{Remedies towards Sustainable Tree Conservation among the Rendille Community}

Table 2, shows probable ways towards conservation challenges among the Rendille. The respondents stated the ways of dealing with the challenges they faced in conservation of the trees in the area, as; creation of awareness $(89.1 \%)$ through formal, informal education and documentation of the indigenous knowledge to guide the locals on the sustainable use of the tree resources, initiation of environmental management committee $(89.1 \%)$, provision of other alternative sources of energy (78.9\%) and control of timber trading $(45.3 \%)$ though the government policies and frameworks to govern forest resources among the Rendille community in Kenya.

Table 1. Conservation challenges on selected tree species

\begin{tabular}{cllll}
\hline Challenges facing conservation & Frequency $(\mathbf{n}=\mathbf{1 2 8})$ & Percent & $\begin{array}{l}\text { Ranks } \\
\text { (1-biggest challenge) }\end{array}$ \\
\hline a) & $\begin{array}{l}\text { Charcoal burning and fuel } \\
\text { wood consumption }\end{array}$ & 108 & 84.4 & 1 \\
b) & 61 & 47.7 & 4 \\
c) & $\begin{array}{l}\text { Climate variability } \\
\text { extremes }\end{array}$ & 94 & 73.4 & 3 \\
d) $\begin{array}{l}\text { Demand for traditional } \\
\text { medicine }\end{array}$ & 99 & 77.3 & 2 \\
e) $\begin{array}{l}\text { Demand for land for } \\
\text { agriculture and settlement }\end{array}$ & 54 & 42.2 & 5 \\
\hline
\end{tabular}

Table 2. Probable ways to curb tree conservation challenges

\begin{tabular}{rlll}
\hline $\begin{array}{l}\text { Dealing with challenges facing } \\
\text { conservation }\end{array}$ & Frequency (n= 128) & Percent & $\begin{array}{l}\text { Ranks } \\
\text { (1-most preferred) }\end{array}$ \\
\hline a) Creation of awareness & 114 & 89.1 & 1 \\
b) Initiation of environmental & 114 & 89.1 & 1 \\
$\quad \begin{array}{l}\text { management committee } \\
\text { c) Use of other alternative }\end{array}$ & 104 & 78.9 & 2 \\
$\quad \begin{array}{l}\text { sources of fuel } \\
\text { d) } \begin{array}{l}\text { Control timber trading and } \\
\text { enforcement of }\end{array}\end{array}$ & 58 & 45.3 & 3 \\
$\quad \begin{array}{l}\text { environmental laws } \\
\text { governing trees }\end{array}$ & 4 & & \\
Others & 4.1 & 4 \\
\hline
\end{tabular}


The respondents preferred creation of awareness and initiation of environmental management committee to curb tree conservation both were ranked $1^{\text {st }}(89.1 \%)$ by the total respondents $(n=128)$. The awareness can be through formal or informal education model to the community on use of tree resources sustainably. According to $[14,15]$ the social, economic, cultural, and other developments have caused a reduction in forest conservation awareness in respect to traditional values in indigenous communities for decades in Kenya. This therefore finds awareness creation through capacity building key among the Rendille community in forest conservation. A study by [16], indicate that environmental conservation is domiciled by enhanced human attitude change which is in line with awareness creation effort indicated by the respondents

\section{CONCLUSION}

Demand for charcoal and tree medicinal value need immediate critical response towards conservation of forest resources among the indigenous Rendille Community in Kenya. Limited conservational knowledge is consequential with existing forest resources in Semi-Arid Lands occupied by pastoral communities in Kenya like the case of the Rendille. It is therefore paramount to build capacity driven both by informal and formal education approach towards sustainability of forests in these communities. This can be through sustainable environmental education where formal and indigenous knowledge is integrated as a discourse to existing forest laws in Kenya.

\section{RECOMMENDATIONS}

1. Integration of Indigenous Knowledge (IK) with the formal education to enhance conservation of the mentioned tree species.

2. Localizing forest conservation laws and policies at communal set-up through partipatory forest management where pastoral communities should act as key stakeholders.

3. Provision of alternative sources of energy to pastoral communities to curb fast loss of forest cover.

4. Engaging indigenous pastoral communities like the Rendille on sustainable use of forest resources.

\section{ACKNOWLEDGEMENT}

We thank the research team from Kenyatta University's School of Environmental Studies and other anonymous reviewers.

\section{COMPETING INTERESTS}

Authors have declared that no competing interests exist.

\section{REFERENCES}

1. Bélisle, Annie Claude, Hugo Asselin, Patrice LeBlanc, and Sylvie Gauthier. Local knowledge in ecological modeling. Ecology and Society. 2018;23:2.

2. Mavhura E, Mushure S. Forest and wildlife resource-conservation efforts based on indigenous knowledge: The case of Nharira community in Chikomba district, Zimbabwe. Forest Policy and Economics. 2019;105:83-90.

3. Khatoon N. Natural resources and biodiversity conservation practices in tawang. In Tawang, Monpas and Tibetan Buddhism in Transition . Springer, Singapore. 2020;89-102.

4. Kosmol J, Müller F, Keßler H. The critical raw materials concept: Subjective, multifactorial and ever-developing. In Factor X. Springer, Cham. 2018;71-92.

5. Chandrakala M, Srinivasan R, Karthika KS. Chapter-7 Gully Erosion and Land Degradation. Current Research in Soil Fertility. 2020;149.

6. Monroe MC, Plate RR, Oxarart A, Bowers $A$, Chaves WA. Identifying effective climate change education strategies: a systematic review of the research. Environmental Education Research. 2019;25(6):791-812.

7. Ramachandra TV. Environment education for ecosystem conservation. Bangalore, India: Capital Publishing Company; 2008.

8. Muhati LG, Olago D, OLaka L. Quantification of carbon stocks in mount marsabit forest reserve, a sub-humid montane forest in northern kenya under anthropogenic disturbance. Global Ecology and Conservation. 2018;14:2351-9894.

9. MSCIDP. Marsabit county integrated development plan 2013-2017. Nairobi: Government Press; 2013.

10. County Government of Marsabit. Second county integrated plan 2018-2022. Nairobi: Government Press; 2018.

11. KNBS. The 2019 Kenya population and housing census. Population by County and 
Sub-County. Nairobi: Government Press; 2019.

12. de Carvalho Balieiro F, de Moraes LFD, Prado RB, de Moura CJR, Santos FM, de Araujo Pereira AP. Ecosystem services in eucalyptus planted forests and mixed and multifunctional planted forests. In Mixed Plantations of Eucalyptus and Leguminous Trees. Springer, Cham. 2020;193-219.

13. Food and Agriculture Organization. Global forest resources assessment 2015. In how are the world's forests changing? (Second edition); 2016. [Online 7 march 2019] URL: http://www.fao.org/3/a-i4793e.pdf
14. Githitho AN. The sacred Mijikenda Kaya forests of coastal Kenya and biodiversity conservation. UNESCO The Importance of Sacred Natural Sites for Biodiversity Conservation, retrieved January. 2003;15:2010.

15. Ouko CA, Mulwa R, Kibugi R, Owuor MA, Zaehringer JG, Oguge NO. Community perceptions of ecosystem services and the management of Mt. Marsabit Forest in Northern

Kenya. Environments. 2018;5(11):121.

16. Braun EM. Brink of extinction: Can we stop nature's decline? Compass Point Books; 2020.

(c) 2021 Ekalo et al.; This is an Open Access article distributed under the terms of the Creative Commons Attribution License (http://creativecommons.org/licenses/by/4.0), which permits unrestricted use, distribution, and reproduction in any medium, provided the original work is properly cited.

Peer-review history:

The peer review history for this paper can be accessed here: https://www.sdiarticle4.com/review-history/70332 